\title{
Circulating CD36 and oxLDL levels are associated with cardiovascular risk factors in young subjects
}

\author{
Luz E Ramos-Arellano', José F Muñoz-Valle², Ulises De la Cruz-Mosso², Aralia B Salgado-Bernabé', \\ Natividad Castro-Alarcón ${ }^{1}$ and Isela Parra-Rojas ${ }^{1 *}$
}

\begin{abstract}
Background: Cardiovascular disease (CVD) results from a combination of abnormalities in lipoprotein metabolism, oxidative stress, chronic inflammation, and susceptibility to thrombosis. Atherosclerosis is the major cause of CVD. CD36 has been shown to play a critical role in the development of atherosclerotic lesions by its capacity to bind and promote endocytosis of oxidized low-density lipoprotein (oxLDL) and is implicated in the formation of foam cells. The purpose of this research was to evaluate whether there is an association of SCD36 and oxLDL levels with cardiovascular risk factors in young subjects.
\end{abstract}

Methods: A total of 188 subjects, 18 to 25 years old, 133 normal-weight and 55 obese subjects from the state of Guerrero, Mexico were recruited in the study. The lipid profile and glucose levels were measured by enzymatic colorimetric assays. Enzyme-linked immunosorbant assays (ELISA) for oxLDL and SCD36 were performed. Statistical analyses of data were performed with Wilcoxon- Mann Whitney and chi-square tests as well as with multinomial regression.

Results: TC, LDL-C, TG, oxLDL and SCD36 levels were higher in obese subjects than in normal-weight controls, as well as, monocyte and platelet counts $(P<0.05)$. Obese subjects had 5.8 times higher risk of sCD36 in the third tertil (>97.8 ng/mL) than normal-weight controls $(P=0.014)$, and 7.4 times higher risk of oxLDL levels in third tertile (>48 U/L) than control group. The subjects with hypercholesterolemia, hypertriglyceridemia, fasting impaired LDL-C had a higher risk of oxLDL levels in the third tertile $(>48 \mathrm{U} / \mathrm{L})$ than the control group $(P<0.05)$.

Conclusions: Circulating CD36 and oxLDL levels are associated with cardiovascular risk factors in young subjects and may be potential early markers for cardiovascular disease (CVD).

Keywords: CD36, OxLDL, Cardiovascular risk factors, Obesity

\section{Background}

Cardiovascular disease (CVD) risk factors such as advanced age, obesity, smoking, hyperlipidemia, diabetes, and hypertension, account for $30-40 \%$ of the worldwide prevalence of this disease [1]. The pathological basis of CVD results from a combination of abnormalities in lipoprotein metabolism, oxidative stress, chronic inflammation, and susceptibility to thrombosis [2]. Atherosclerosis is the major cause of CVD [3], it is considered a chronic inflammatory disease of the arterial wall that underlies many of the common causes of cardiovascular morbidity

\footnotetext{
*Correspondence: iprojas@yahoo.com

'Laboratorio de Investigación en Obesidad y Diabetes, Unidad Académica de Ciencias Químico Biológicas, Universidad Autónoma de Guerrero,

Chilpancingo, Guerrero, México

Full list of author information is available at the end of the article
}

and mortality, including myocardial infarction (MI), cerebrovascular and peripheral vascular disease [4].

A key process in the pathogenesis of atherosclerosis is the deposition of cholesterol in the arterial wall. Lipoproteins are involved in this process, including cholesterol carried by very low-density (VLDL), remnant lipoproteins and low-density lipoproteins (LDL), particularly the small and dense forms; conversely, cholesterol is carried away from the arterial wall by high-density lipoprotein (HDL) [5].

Oxidative modification of LDL (oxLDL) in the arterial wall is central to the pathogenesis of atherosclerosis [6]. OxLDL is associated with carotid intimal-media thickness, unstable plaques in the coronary and carotid arteries, impaired brachial and coronary endothelial 
function, and coronary artery disease [7]. When oxLDL loses its ability to bind to LDL receptors, this interferes with its normal processing and as a result gains affinity for a family of proteins called scavenger receptors [8]. This leads to macrophage activation, foam-cell formation, secretion of growth factors and proinflammatory cytokines, thereby promoting plaque formation $[9,10]$.

CD36, an $88 \mathrm{kDa}$ glycoprotein, was originally described as platelet receptor glycoprotein which belongs to the class B scavenger receptor family $[11,12]$. CD36 is expressed on an extensive range of cells and tissues, including microvascular endothelial cells, monocytes and macrophages, dendritic cells, adipocytes, keratinocytes, cardiac and skeletal muscle, retinal pigment epithelium, microglia, reticulocytes, breast, gut, renal epithelium, platelets, hepatocytes, smooth muscle cells and binds to a diverse array of ligands [13-16]. CD36 is best characterized as a free fatty acid transporter involved in different biological processes like angiogenesis, inflammation, lipid metabolism, atherosclerosis and platelet activation [17].

Monocyte/macrophage CD36 has been shown to play a critical role in the development of atherosclerotic lesions by its capacity to bind and promote endocytosis of oxLDL, and is also implicated in the formation of foam cells $[18,19]$. Moreover, the pathogenic role of oxLDL in atherosclerosis largely depends on CD36 [20].

A soluble form of CD36 (sCD36), a marker of altered tissue CD36 expression, was recently identified in human plasma, and elevated levels were found in obesity and type 2 diabetes. In this regard, $\mathrm{sCD} 36$ in plasma has been reported up to 4-fold higher in obese T2D-patients compared to lean healthy control subjects [21]. The circulating concentration of CD36 is also associated with markers of liver injury in subjects with altered glucose tolerance [22]. A recent study revealed that soluble CD36 in plasma correlates significantly with markers of atherosclerosis, insulin resistance and fatty liver in a non-diabetic healthy population [23]. Due to the widespread tissue expression of CD36 and its broad range of functions it is difficult to foresee which specific pathological processes may reflect alterations in sCD36 [24]. However, a recent study showed that sCD36 is not a proteolytic product, but it is associated with a specific subset of circulating microparticles (MPs) that can readily be analyzed and which originate mainly from platelets in normal subjects [25]. In this regard, the aim of this research was to evaluate whether there is an association of sCD36 and oxLDL levels with cardiovascular risk factors in young subjects.

\section{Methods}

\section{Subjects}

A total of 188 subjects were randomly selected, 18 to 25 years old, 133 normal-weight controls (BMI 18.5 to
$24.9 \mathrm{~kg} / \mathrm{m} 2$ ) and 55 obese subjects (BMI $\geq 30 \mathrm{~kg} / \mathrm{m} 2$ ) from the state of Guerrero, Mexico. There were 117 women and 71 men; participants were not under any medication or had evidence of metabolic disease other than obesity. All subjects gave their written informed consent previous explanation of the purpose and nature of the study. The protocol was approved by the Research Ethics Committee of the University of Guerrero.

\section{Blood pressure}

Blood pressure was measured in the sitting position with the use of an automatic sphygmomanometer on the left arm after $10 \mathrm{~min}$ rest. The systolic blood pressure (SBP) and diastolic blood pressure (DBP) were calculated from two readings with a minimal interval of $10 \mathrm{~min}$. Hypertension was defined as mean SBP $\geq 140 \mathrm{mmHg}$ and/or DBP $\geq 90 \mathrm{mmHg}$ [26].

\section{Biochemical analysis}

A venous blood sample of $5 \mathrm{~mL}$ was obtained from each subject after at least a 12 hours fasting. All serum lipid levels and glucose were determined by enzymatic methods with commercially available kits (Spinreact). Abnormal biochemical levels were identified when total-cholesterol (TC) $\geq 200 \mathrm{mg} / \mathrm{dL}$, triglycerides (TG) $\geq 150 \mathrm{mg} / \mathrm{dL}$, lowdensity lipoprotein cholesterol (LDL-C) $>100 \mathrm{mg} / \mathrm{dL}$, highdensity lipoprotein cholesterol (HDL-C) $<40 \mathrm{mg} / \mathrm{dL}$ and glucose $>100 \mathrm{mg} / \mathrm{dL}$, based on the criteria of the National Cholesterol Education Program (NCEP) Expert Panel on Detection, Evaluation, and Treatment of High Blood Cholesterol in Adults (Adult Treatment Panel III) [27].

\section{Determination of $s C D 36$ and oxLDL levels}

Enzyme-linked immunosorbant assays (ELISA) for oxLDL (Mercodia Oxidized LDL ELISA) and sCD36 (Human soluble CD36 ELISA, kit-Aviscera Bioscience) were performed, according to the manufacturer's instructions, with an intra-assay $\mathrm{CV}<6 \%$ and interassay $\mathrm{CV}<7 \%$ for oxLDL ELISA assay, and an intra-assay $\mathrm{CV}<5 \%$ and interassay $\mathrm{CV}<9 \%$ for CD36 ELISA assay.

\section{Statistical analysis}

The statistical analyses were performed with the statistical software package SPSS 15.0 and STATA software 9.0. Quantitative variables were expressed as medians and 25th to 75th percentiles and significant differences between groups were determined using the WilcoxonMann Whitney test. Qualitative variables were expressed as percentages and the differences between groups were determined using the chi-square test. The association analysis between serum levels of oxLDL and sCD36 with lipid phenotypes was carried out with multinomial regression, where a $P$ value $<0.05$ was considered statistically significant. 


\section{Results}

General and biochemical characteristics

General and biochemical characteristics of the study subjects are shown in Table 1. Measurements of body weight, height, systolic and diastolic blood pressure, prevalence of hypertension, and TC, LDL-C, TG, sCD36 and oxLDL levels were higher in obese subjects than in normal-weight controls, as well as, the monocyte and platelet counts $(P<0.05)$. There were no significant differences by gender $(P=0.162)$.

\section{Correlations between sCD36 and oxLDL levels with selected variables}

In all subjects studied, sCD36 correlated significantly with weight, BMI, waist, hip, waist-to-hip ratio, $\%$ fat, $\%$ fat mass, LDL-C, oxLDL and monocyte count. Obese subjects showed a high correlation among BMI and sCD36 $(\mathrm{r}=0.50, P=0.028)$ (Table 2$)$. The oxLDL levels correlated positively with weight, BMI, waist, hip, waist-

Table 1 Anthropometric and biochemical variables by group

\begin{tabular}{|c|c|c|c|}
\hline Variables & Normal weight & Obesity & $P$ value \\
\hline$n$ & 133 & 55 & - \\
\hline Age (years) & $20(19-22)$ & $21(20-23)$ & 0.005 \\
\hline Gender & & & 0.162 \\
\hline Female (\%) & $87(65)$ & $30(55)$ & \\
\hline Male (\%) & $46(35)$ & $25(45)$ & \\
\hline Weight (kg) & $54.5(49.2-59.4)$ & 90.9 (79.1-99.9) & 0.001 \\
\hline Height (cm) & $158.7(153.0-167.5)$ & $163.5(155-171)$ & 0.036 \\
\hline BMI $\left(\mathrm{kg} / \mathrm{m}^{2}\right)$ & $21.5(20.0-23.4)$ & $33.1(31.3-35.3)$ & 0.001 \\
\hline SBP $(\mathrm{mmHg})$ & $104(98-112)$ & $115(112-121)$ & 0.001 \\
\hline $\mathrm{DBP}(\mathrm{mmHg})$ & $68(61-73)$ & $70(67-77)$ & 0.003 \\
\hline Hypertension & & & 0.001 \\
\hline No & $124(93.9)$ & $35(67.3)$ & \\
\hline Yes & $8(6.1)$ & $17(32.7)$ & \\
\hline $\mathrm{TC}(\mathrm{mg} / \mathrm{dL})$ & $152(136-173)$ & 160 (137-195) & 0.057 \\
\hline $\mathrm{HDL}-\mathrm{C}(\mathrm{mg} / \mathrm{dL})$ & $43(38-54)$ & $44(38-47)$ & 0.717 \\
\hline LDL-C (mg/dL) & $89(61-116)$ & $117(88-157)$ & 0.001 \\
\hline TG (mg/dL) & $72(56-98)$ & $121(75-89)$ & $<0.001$ \\
\hline Glucose (mg/dL) & $83(75-89)$ & $83(77-90)$ & 0.386 \\
\hline Monocytes (\%) & $7(5-9)$ & $9(7-11)$ & 0.0005 \\
\hline Platelets $\left(10^{3} / \mathrm{mm}^{3}\right)$ & $247(215-289)$ & $265(232-307)$ & 0.048 \\
\hline sCD36 (ng/mL) & $32.3(16.8-102.4)$ & $146.3(76.7-694.7)$ & 0.002 \\
\hline oxLDL (U/L) & $35.4(27.9-47.1)$ & $51.5(38.0-59.7)$ & $<0.001$ \\
\hline
\end{tabular}

BMI, Body Mass Index; SBP, Systolic Blood Pressure; DBP, Diastolic Blood Pressure; TC, Total Cholesterol; HDL-C, High-Density Lipoprotein Cholesterol; LDL-C, Low-Density Lipoprotein Cholesterol; TG,Triglyceride; oxLDL, oxidized LowDensity Lipoprotein. Values were presented as median (percentile 25-75th). Difference between genders was determined by the Wilcoxon-Mann-Whitney test. Hypertension data were presented in ( $\mathrm{n}$ ) and percentages; the difference between genders was determined by chi-square test. to-hip ratio,\% fat,\% fat mass, and TC, TG, LDL-C, sCD36 and monocyte count in all subjects. In normal-weight and obese groups, oxLDL levels showed a high correlation with weight, BMI, waist, waist-to-hip ratio,\% fat mass, and TG, LDL-C levels and monocyte count (Table 3).

\section{Circulating CD36 and oxLDL levels according to metabolic abnormalities}

Subjects with hypertriglyceridemia and hypertension had higher levels of sCD36, while oxLDL levels were higher in subjects with hypercholesterolemia, hypertriglyceridemia, LDL-C and hypertension compared to those subjects without these abnormalities $(P<0.05)$ (Table 4$)$.

\section{Association of cardiovascular risk factors with sCD36 and oxLDL levels}

For the association analysis with cardiovascular risk factors, sCD36 was classified into tertiles (first tertile $<23.3 \mathrm{ng} / \mathrm{mL}$, second tertile 23.3 to $97.8 \mathrm{ng} / \mathrm{mL}$ and third tertile $>97.8 \mathrm{ng} /$ $\mathrm{mL})$, since there are no established reference values. Obese subjects had 5.8 times higher risk of sCD36 in the third tertile than normal-weight controls, adjusted for age and gender $(P=0.014)$ (Table 5$)$. The oxLDL levels were also classified into tertiles (first tertile $<31.9 \mathrm{U} / \mathrm{L}$, second tertile 31.9 to $48.0 \mathrm{U} / \mathrm{L}$ and third tertile $>48.0 \mathrm{U} / \mathrm{L}$ ) in order to analyze their association with cardiovascular risk factors. Table 5 shows that subjects with hypercholesterolemia had 7.5 times higher risk of oxLDL levels in the third tertile than subjects without these abnormalities. Individuals

\begin{tabular}{|c|c|c|c|c|c|c|}
\hline \multirow[t]{2}{*}{ Variables } & \multicolumn{2}{|c|}{ All subjects } & \multicolumn{2}{|c|}{ Normal weight } & \multicolumn{2}{|c|}{ Obesity } \\
\hline & $r$ & $p$ & $r$ & $p$ & $r$ & $p$ \\
\hline Weight (kg) & 0.29 & 0.004 & 0.14 & 0.217 & 0.41 & 0.073 \\
\hline Height (cm) & 0.03 & 0.774 & 0.04 & 0.724 & 0.15 & 0.534 \\
\hline BMI $\left(\mathrm{kg} / \mathrm{m}^{2}\right)$ & 0.32 & 0.001 & 0.17 & 0.150 & 0.50 & 0.028 \\
\hline Waist (cm) & 0.30 & 0.003 & 0.13 & 0.2474 & 0.30 & 0.210 \\
\hline Hip (cm) & 0.31 & 0.002 & 0.18 & 0.1190 & 0.30 & 0.201 \\
\hline Waist-to-hip ratio & 0.23 & 0.026 & 0.001 & 0.988 & 0.02 & 0.931 \\
\hline$\%$ Fat & 0.32 & 0.001 & 0.19 & 0.097 & -0.02 & 0.909 \\
\hline$\%$ Fat mass & 0.35 & 0.0006 & 0.22 & 0.058 & 0.30 & 0.203 \\
\hline Glucose (mg/dL) & -0.15 & 0.132 & -0.16 & 0.168 & -0.01 & 0.954 \\
\hline $\mathrm{TC}(\mathrm{mg} / \mathrm{dL})$ & -0.05 & 0.609 & -0.15 & 0.201 & 0.16 & 0.479 \\
\hline TG (mg/dL) & 0.15 & 0.134 & -0.001 & 0.991 & 0.33 & 0.151 \\
\hline $\mathrm{HDL}-\mathrm{C}(\mathrm{mg} / \mathrm{dL})$ & 0.07 & 0.456 & 0.10 & 0.373 & -0.06 & 0.771 \\
\hline LDL-C (mg/dL) & 0.21 & 0.038 & 0.02 & 0.803 & 0.23 & 0.325 \\
\hline oxLDL (U/L) & 0.25 & 0.024 & 0.06 & 0.623 & 0.29 & 0.334 \\
\hline Monocytes (\%) & 0.33 & 0.001 & 0.22 & 0.056 & 0.20 & 0.376 \\
\hline Platelets $\left(10^{3} / \mathrm{mm}^{3}\right)$ & 0.15 & 0.142 & 0.03 & 0.741 & 0.23 & 0.309 \\
\hline
\end{tabular}

$\mathrm{r}=$ Spearman correlation coefficient; $p=p$ value. 
Table 3 Correlation between oxLDL levels and selected variables

\begin{tabular}{|c|c|c|c|c|c|c|}
\hline \multirow[t]{2}{*}{ Variables } & \multicolumn{2}{|c|}{ All subjects } & \multicolumn{2}{|c|}{ Normal weight } & \multicolumn{2}{|c|}{ Obesity } \\
\hline & $r$ & $p$ & $r$ & $p$ & $r$ & $p$ \\
\hline Weight (kg) & 0.43 & 0.0001 & 0.23 & 0.009 & 0.31 & 0.026 \\
\hline Height (cm) & 0.05 & 0.438 & -0.06 & 0.499 & 0.17 & 0.234 \\
\hline BMI (kg/m²) & 0.51 & 0.0001 & 0.40 & $<0.001$ & 0.37 & 0.009 \\
\hline Waist (cm) & 0.52 & 0.0001 & 0.39 & $<0.001$ & 0.38 & 0.007 \\
\hline Hip (cm) & 0.36 & 0.0001 & 0.10 & 0.225 & 0.21 & 0.139 \\
\hline Waist-to-hip ratio & 0.53 & 0.0001 & 0.42 & $<0.001$ & 0.30 & 0.034 \\
\hline$\%$ Fat & 0.32 & 0.0001 & 0.13 & 0.124 & 0.09 & 0.516 \\
\hline$\%$ Fat mass & 0.41 & 0.0001 & 0.21 & 0.014 & 0.39 & 0.005 \\
\hline Glucose (mg/dL) & -0.10 & 0.182 & -0.19 & 0.027 & 0.12 & 0.398 \\
\hline $\mathrm{TC}(\mathrm{mg} / \mathrm{dL})$ & 0.32 & $<0.001$ & 0.17 & 0.053 & 0.67 & $<0.001$ \\
\hline TG (mg/dL) & 0.47 & $<0.001$ & 0.38 & $<0.001$ & 0.33 & 0.018 \\
\hline $\mathrm{HDL}-\mathrm{C}(\mathrm{mg} / \mathrm{dL})$ & 0.04 & 0.557 & 0.04 & 0.621 & 0.11 & 0.422 \\
\hline LDL-C (mg/dL) & 0.43 & $<0.001$ & 0.33 & 0.0001 & 0.53 & 0.0001 \\
\hline sCD36 (ng/mL) & 0.25 & 0.024 & 0.06 & 0.623 & 0.29 & 0.334 \\
\hline Monocytes (\%) & 0.40 & $<0.001$ & 0.31 & 0.0003 & 0.34 & 0.020 \\
\hline Platelets $\left(10^{3} / \mathrm{mm}^{3}\right)$ & 0.01 & 0.889 & 0.01 & 0.879 & -0.15 & 0.293 \\
\hline
\end{tabular}

$\mathrm{r}=$ Spearman correlation coefficient; $p=p$ value.

with impaired fasting LDL-C had 4.5 times higher risk of oxLDL levels in the third tertile and subjects with hypertriglyceridemia had 17.9 times higher risk of oxLDL levels in the third tertile, adjusted for age, gender and BMI. Likewise, obese individuals had 7.4 times higher risk of oxLDL levels in third tertile than controls, adjusted for age and gender.

\section{Discussion}

In this research, we found a higher prevalence of hypertension in obese subjects $(32.7 \%)$ than in normal weight subjects $(6.1 \%)$, with a prevalence of $13.6 \%$ in the total study subjects. These findings are similar to those reported in another study in U.S. teenagers; where hypertension showed a prevalence of $30 \%$ in obese subjects [28]. It is known that the increase sodium reabsorption induced by angiotensin II produced by adipocytes affects renal natriuresis, so that obese subjects need higher blood pressure levels than normal weight subjects to maintain a balance between the sodium intake and renal diuresis [29].

In this study, as in previous studies the lipid profile (TC, LDL-C and TG) was higher in obese subjects than normal-weight controls. This may be due to increased adiposity since adipose tissue undergoes morphological and physiological changes which include the release of proinflammatory cytokines such as tumour necrosis factor alpha (TNF- $\alpha$ ), and in turn, decrease insulin sensitivity and increase lipolysis. These morphological changes contribute to insulin resistance and dyslipidemia [30].
Table 4 sCD36 and oxLDL levels according to metabolic abnormalities

\begin{tabular}{lcc}
\hline Variables (n) & $\begin{array}{c}\text { sCD36 levels } \\
\text { (ng/mL) }\end{array}$ & $\begin{array}{c}\text { oxLDL levels } \\
\text { (U/L) }\end{array}$ \\
\hline $\begin{array}{l}\text { Fasting glucose } \\
(>100 \mathrm{mg} / \mathrm{dL})\end{array}$ & & \\
No (176) & $47.7(18.4-219.9)$ & $37.8(29.5-50.6)$ \\
Yes (12) & $62.2(16.7-200.4)$ & $52.7(30.1-60.5)$ \\
& $P=0.93$ & $P=0.20$ \\
Hypercholesterolemia & & \\
( $200 \mathrm{mg} / \mathrm{dL})$ & & \\
No (162) & $44.9(17.3-223.6)$ & $36.7(29.1-48.5)$ \\
Yes (26) & $74.8(25.7-98.7)$ & $54.5(45.5-65.0)$ \\
& $P=0.55$ & $P=0.0002$ \\
Fasting LDL-C & & \\
>100 mg/dL) & & \\
No (95) & $47.7(17.2-208.2)$ & $32.4(27.8-45.6)$ \\
Yes (93) & $74.8(21.8-270.4)$ & $47.1(35.8-57.1)$ \\
& $P=0.30$ & $P=0.0001$ \\
Fasting HDL-C \\
$(<40 \mathrm{mg} / \mathrm{dL})$
\end{tabular}

Hypertriglyceridemia $(\geq 150 \mathrm{mg} / \mathrm{dL}$ )

No (161)

$43.1(16.7-190.6) \quad 36.1(28.2-48.1)$

Yes (27)

$180.3(66.01-2295) \quad 52.5(48.5-59.7)$

$$
P=0.01 \quad P=0.0001
$$

Hypertension

(SBP $\geq 140 \mathrm{mmHg}, \mathrm{DBP} \geq 90 \mathrm{mmHg}$ )

No (161)

$34.1(16.7-190.6) \quad 37.6(29-119.0)$

Yes (27)

$79.8(66.01-200.4) \quad 48.0(31.5-58.8)$

$$
P=0.03 \quad P=0.1218
$$

The values were presented as median (percentile $25-75$ th). The difference between genders was determined by the Wilcoxon-Mann-Whitney test.

An interesting finding in this study was that obese subjects have a higher number of monocytes and platelets than the normal-weight subjects. The leukocyte count is considered as an indicator of inflammatory status in obesity [31]. In addition, research has shown that adults and children with obesity have higher levels of leukocytes, mainly monocytes, compared with adults and children of normal weight [32-34]. Regarding increased platelet count in subjects with obesity, similar findings have been shown in other studies, where the platelet count is higher in teenagers and adults with obesity than normal weight subjects $[35,36]$. In relation to cytokines, it has been shown that interleukin-6 (IL-6) induces differentiation of megakaryocytes into platelets and that IL- 6 is produced by adipose tissue $[37,38]$. Furthermore, it has been reported 
Table 5 Association of cardiovascular risk factors with sCD36 and oxLDL levels

\begin{tabular}{|c|c|c|c|c|c|c|}
\hline \multirow[t]{2}{*}{ Variables } & \multicolumn{3}{|c|}{ sCD36 levels (>97.8 ng/mL) } & \multicolumn{3}{|c|}{ oxLDL levels (>48 U/L) } \\
\hline & OR $(95 \% \mathrm{Cl})$ & $R^{2}$ & $p$ value & OR $(95 \% \mathrm{Cl})$ & $R^{2}$ & $p$ value \\
\hline Hypercholesterolemia & $0.9(0.14-5.75)$ & 0.098 & $0.932^{*}$ & $7.5(1.80-31.15)$ & 0.155 & $0.006^{*}$ \\
\hline Impaired fasting LDL-C & $0.7(0.22-2.45)$ & 0.085 & $0.622^{*}$ & $4.5(1.79-11.31)$ & 0.152 & $0.001^{*}$ \\
\hline Impaired fasting $\mathrm{HDL}-\mathrm{C}$ & $0.4(0.15-1.46)$ & 0.103 & $0.195^{*}$ & $0.3(0.10-0.63)$ & 0.147 & $0.003^{*}$ \\
\hline Hypertriglyceridemia & $5.3(0.50-55.87$ & 0.094 & $0.164^{*}$ & $17.9(2.03-158.92)$ & 0.154 & $0.009^{*}$ \\
\hline Hypertension & $4.5(0.45-44.63)$ & 0.098 & $0.197^{*}$ & $0.51(0.13-1.98)$ & 0.117 & $0.336^{*}$ \\
\hline Obesity & $5.8(1.43-24.05)$ & 0.070 & $0.014^{* *}$ & $7.4(2.82-19.60)$ & 0.80 & $<0.001 * *$ \\
\hline
\end{tabular}

*Adjusted for age, gender and $\mathrm{BMI},{ }^{* *}$ Adjusted for age and gender.

that obese individuals have increased levels of IL-6 [39], which may explain the increase in platelets in an obese state.

In this study, we observed that $\mathrm{sCD} 36$ was higher in obese subjects than in normal weight subjects (143.3 ng/ $\mathrm{mL}$ vs. $32.3 \mathrm{ng} / \mathrm{mL}, P=0.002$ ), these results are congruent with previous studies [21,40]. This may be due to the increased number of platelets and monocytes shown in obese subjects, as was recently reported that the circulating form of the CD36 receptor is associated with microparticles mainly originated of platelets, leukocytes and endothelial cells as a result of stimuli or apoptosis $[8,25]$. These microparticles have been found increased in subjects with insulin resistance and obese with type 2 diabetes, due to presence of a low-grade inflammation [41-43]. In this study, we observed that serum oxLDL levels were higher in obese subjects than in control group (51.5 U/L vs. 35.4 U/L), these results are consistent with those reported in other studies [44]. This may be due to the increase oxidative stress in an obese state, which favors the oxidation of LDL-C $[45,46]$.

We observed a high correlation of sCD36 with BMI in obese subjects $(\mathrm{r}=50, P=0.028)$, similar results have been reported in previous studies [47]. In addition, oxLDL levels showed a strong correlation with BMI, TG and LDL-C in subjects with and without obesity. Such correlations are similar to those reported in other studies $[48,49]$.

In this research, sCD36 in the third tertile $(>97.8 \mathrm{ng} / \mathrm{mL})$ were associated with obesity, although there is a lack of studies that support this association, sCD36 have been correlated with BMI $[47,50]$. Higher sCD36 in obese subjects than in normal weight subjects have also been reported in other studies $[21,43]$. Furthermore, it is proposed that high CD36 levels may be a marker of increased CD36 expression known from a number of tissues that are associated with the metabolic syndrome; macrophage infiltration and low-grade inflammation in abdominal obesity, which may lead to dyslipidemia and peroxidation of lipoproteins [24].

We also found that oxLDL levels in third tertile $(>48.0$ $\mathrm{U} / \mathrm{L}$ ) were associated with hypercholesterolemia, impaired fasting LDL-C, hypertriglyceridemia and obesity.
The association between dyslipidemia and oxidation of LDL has been demonstrated in individuals in the pre-diabetic state [48]. It has also been observed in middle-aged people that obesity and dyslipidemia are the strongest predictors of oxLDL levels [51]. The association between cardiovascular disease (CVD) and oxLDL has been demonstrated in others studies [52-55]. Considering the associations shown in this study (sCD36 and oxLDL levels with traditional cardiovascular risk factors such as obesity, hypercholesterolemia, hypertriglyceridemia and impaired fasting LDL-C), measuring sCD36 and oxLDL levels can be incorporated into cardiovascular risk factors in young subjects for early diagnosis of cardiovascular disease.

Our research has some limitations. We could not study the associations between sCD36 and oxLDL levels with early atherosclerosis. As our study is comprised of young subjects without clinical atherosclerotic diseases, we were only able to study associations between traditional cardiovascular risk factors with sCD36 and oxLDL levels. Whether the increase of these markers in young subjects is associated with the silent phase of atherosclerosis remains to be elucidated. The authors believe that a greater obese group is desirable to improve the power of the study.

\section{Conclusions}

In this research, sCD36 and oxLDL levels are associated with cardiovascular risk factors, particularly with obesity, hypercholesterolemia, impaired fasting LDL-C and HDL-C and hypertriglyceridemia. Therefore, sCD36 and oxLDL levels may be potential early markers for CVD. However, these associations should be investigated in further studies.

\section{Competing interests}

The authors declare that they have no competing interests.

\section{Authors' contributions}

LERA performed ELISA assays, statistical analysis and writing the manuscript. UDCM carried out the immunoassays. ABSB performed biochemical

measurements and quality control. JFMV and NCA participated in the critical revision of the manuscript. IPR conceived the study and participated in

manuscript preparation. All authors read and approved the final manuscript. 


\section{Acknowledgements}

We are grateful to Citlalli Tornez Benitez, Zulema Quinto Flores and José Alberto González de la Cruz that participated in the patient enrollment and data collection. This study was supported by grants to IPR of the Fondo SEP-CONACYT (No. 106734) and Programa de Fortalecimiento Académico del Posgrado de Alta Calidad (1010/455/2013 C-677/2013). LERA received a fellowship of CONACYT (No. 236905).

\section{Author details}

'Laboratorio de Investigación en Obesidad y Diabetes, Unidad Académica de Ciencias Químico Biológicas, Universidad Autónoma de Guerrero, Chilpancingo, Guerrero, México. ${ }^{2}$ Departamento de Biología Molecular y Genómica, Instituto de Investigación en Ciencias Biomédicas, Centro Universitario de Ciencias de la Salud, Universidad de Guadalajara, Guadalajara, Jalisco, México.

Received: 8 December 2013 Accepted: 23 April 2014 Published: 28 April 2014

\section{References}

1. Lin CM, Li CY: Prevalence of Cardiovascular Risk Factors in Taiwanese Healthcare Workers. Ind Health 2009, 47(4):411-418.

2. Ros E: Nuts and novel biomarkers of cardiovascular disease. Am J Clin Nutr 2009, 89(5):1649S-1656S.

3. Scott J: Pathophysiology and biochemistry of cardiovascular disease. Curr Opin Genet Dev 2004, 14(3):271-279.

4. Douglas G, Channon KM: The pathogenesis of atherosclerosis. Medicine 2010, 38(8):397-402.

5. Glaudemans AW, Slart RH, Bozzao A, Bonanno E, Arca M, Dierckx RA, Signore A: Molecular imaging in atherosclerosis. Eur J Nucl Med Mol Imaging 2010, 37(12):2381-2397.

6. Lakshmy R, Ahmad D, Abraham RA, Sharma M, Vemparala K, Das S, Reddy KS, Prabhakaran D: Paraoxonase gene Q192R \& L55M polymorphisms in Indians with acute myocardial infarction \& association with oxidized low density lipoprotein. Indian J Med Res 2010, 131:522-529.

7. Rosoky RM, Wolosker N, Nasser M, Zerati AE, Gidlund M, Puech-Leão P: Oxidized low-density lipoprotein and ankle-brachial pressure index in patients with clinically evident peripheral arterial disease. Clinics 2010, 65(4):383-387.

8. Silverstein RL: Inflammation, atherosclerosis, and arterial thrombosis: role of the scavenger receptor CD36. Cleve Clin J Med 2009, 76(2):S27-S30.

9. Rasouli N, Yao-Borengasser A, Varma V, Spencer HJ, McGehee RE Jr, Peterson CA, Mehta JL, Kern PA: Association of scavenger receptors in adipose tissue with insulin resistance in nondiabetic humans. Arterioscler Thromb Vasc Biol 2009, 29(9):1328-1335.

10. Crucet M, Wüst SJ, Spielmann P, Lüscher TF, Wenger RH, Matter CM: Hypoxia enhances lipid uptake in macrophages: Role of the scavenger receptors Lox1, SRA, and CD36. Atherosclerosis 2013, 229(1):110-117.

11. Cho S, Kim E: CD36: a multi-modal target for acute stroke therapy. J Neurochem 2009, 109(1):126-132.

12. Cho S: CD36 as a therapeutic target for endothelial dysfunction in stroke. Curr Pharm Des 2012, 18(25):3721-3730.

13. Febbraio M, Silverstein RL: CD36: Implications in Cardiovascular Disease. Int J Biochem Cell Biol 2007, 39(11):2012-2030.

14. Erdman LK, Cosio G, Helmers AJ, Gowda DC, Grinstein S, Kain KC: CD36 and TLR interactions in inflammation and phagocytosis: implications for malaria. J Immunol 2009, 183(10):6452-6459.

15. Glintborg D, Højlund K, Andersen M, Henriksen JE, Beck-Nielsen H, Handberg A: Soluble CD36 and risk markers of insulin resistance and atherosclerosis are elevated in polycystic ovary syndrome and significantly reduced during pioglitazone treatment. Diabetes Care 2008, 31(2):328-334.

16. Ghosh A, Li W, Febbraio M, Espinola RG, McCrae KR, Cockrell E, Silverstein RL: Platelet CD36 mediates interactions with endothelial cell-derived microparticles and contributes to thrombosis in mice. J Clin Invest 2008, 118(5):1934-1943.

17. Petta S, Handberg A, Marchesini G, Cammà C, Di Marco V, Cabibi D, Macaluso FS, Craxi A: High sCD36 plasma level is associated with steatosis and its severity in patients with genotype 1 chronic hepatitis $C$. J Viral Hepat 2013, 20(3):174-182.

18. Collot-Teixeira S, Martin J, McDermott-Roe C, Poston R, McGregor JL: CD36 and macrophages in atherosclerosis. Cardiovasc Res 2007, 1(75):468-477.
19. Montano EN, Boullier A, Almazan F, Binder CJ, Witztum JL, Hartvigsen K: Development and Application of a Non-Radioactive Binding Assay of Oxidized LDL to Macrophage Scavenger Receptors. J Lipid Res 2013, 54(11):3206-3214.

20. Yu XH, Fu YC, Zhang DW, Yin K, Tang CK: Foam cells in atherosclerosis. Clin Chim Acta 2013, 424:245-252.

21. Handberg A, Levin $K$, Højlund $K$, Beck-Nielsen $H$ : Identification of the oxidized low-density lipoprotein scavenger receptor CD36 in plasma. novel marker of insulin resistance. A Circulation 2006, 114:1169-1176.

22. Fernández-Real JM, Handberg A, Ortega F, Højlund K, Vendrell J, Ricart W: Circulating soluble CD36 is a novel marker of liver injury in subjects with altered glucose tolerance. J Nutr Biochem 2009, 20(6):477-484.

23. Handberg A, Højlund K, Gastaldelli A, Flyvbjerg A, Dekker JM, Petrie J, Piatti P, Beck-Nielsen H: Plasma sCD36 is associated with markers of atherosclerosis, insulin resistance and fatty liver in a nondiabetic healthy population. J Intern Med 2012, 271:294-304.

24. Koonen DP, Jensen MK, Handberg A: Soluble CD36- a marker of the (pathophysiological) role of CD36 in the metabolic syndrome? Arch Physiol Biochem 2011, 117(2):57-63.

25. Alkhatatbeh MJ, Mhaidat NM, Enjeti AK, Lincz LF, Thorne RF: The putative diabetic plasma marker, soluble CD36, is non-cleaved, non-soluble and entirely associated with microparticles. J Thromb Haemost 2011, 9(4):844-851.

26. 1999 World Health Organization-International Society of Hypertension Guidelines for the Management of Hypertension: Guidelines Subcommittee. J Hypertens 1999, 17(2):151-183.

27. National Cholesterol Education Program (NCEP) Expert Panel on Detection: Evaluation, and Treatment of High Blood Cholesterol in Adults (Adult Treatment Panel III). Circulation 2002, 106(25):3143-3421.

28. McNiece KL, Poffenbarger TS, Turner JL, Franco KD, Sorof JM, Portman RJ: Prevalence of hypertension and pre-hypertension among adolescents. J Pediatr 2007, 150(6):640-644.

29. Francischetti EA, Genelhu VA: Obesity-hypertension: an ongoing pandemic. Int J Clin Pract 2007, 61(2):269-280.

30. Martin LJ, Woo JG, Daniels SR, Goodman E, Dolan LM: The Relationships of Adiponectin with Insulin and Lipids Are Strengthened with Increasing Adiposity. J Clin Endocrinol Metab 2005, 90(7):4255-4259.

31. Schipper HS, Nuboer R, Prop S, van den Ham HJ, de Boer FK, Kesmir C, Mombers IM, van Bekkum KA, Woudstra J, Kieft JH, Hoefer IE, de Jager W, Prakken B, van Summeren M, Kalkhoven E: Systemic inflammation in childhood obesity: circulating inflammatory mediators and activated CD14++ monocytes. Diabetologia 2012, 55(10):2800-2810.

32. Zaldivar F, McMurray RG, Nemet D, Galassetti P, Mills PJ, Cooper DM: Body fat and circulating leukocytes in children. Int J Obes 2006, 30(6):906-911.

33. Kullo IJ, Hensrud DD, Allison TG: Comparison of numbers of circulating blood monocytes in men grouped by body mass index $(<25,25$ to $<30,>$ or $=30)$. Am J Cardiol 2002, 89(12):1441-1443.

34. Nieman DC, Henson DA, Nehlsen-Cannarella SL, Ekkens M, Utter AC, Butterworth $D E$, Fagoaga OR: Influence of obesity on immune function. J Am Diet Assoc 1999, 99(3):294-299

35. Foschini D, Santos RV, Prado WL, de Piano A, Lofrano MC, Martins AC, Carnier J, Caranti DA, Sanches Pde L, Tock L, Mello MT, Tufik S, Dâmaso AR: Platelet and leptin in obese adolescents. J Pediatr (Rio J) 2008, 84(6):516-521.

36. Samocha-Bonet D, Justo D, Rogowski O, Saar N, Abu-Abeid S, Shenkerman G, Shapira I, Berliner S, Tomer A: Platelet counts and platelet activation markers in obese subjects. Mediators Inflamm 2008, 2008:834153. doi:10.1155/2008/834153.

37. Kaser A, Brandacher G, Steurer W, Kaser S, Offner FA, Zoller H, Theurl I, Widder W, Molnar C, Ludwiczek O, Atkins MB, Mier JW, Tilg H: Interleukin-6 stimulates thrombopoiesis through thrombopoietin: role in inflamatory thrombocytosis. Blood 2001, 98(9):2720-2725.

38. Hill RJ, Warren MK, Stenberg P, Levin J, Corash L, Drummond R, Baker G, Levin $F$, Mok Y: Stimulation of megakaryocytopoiesis in mice by human recombinant interleukin-6. Blood 1991, 77(1):42-48.

39. Lyngsø D, Simonsen L, Bülow J: Interleukin-6 production in human subcutaneous abdominal adipose tissue: the effect of exercise. J Physiol 2002, 543(1):373-378.

40. Handberg A, Norberg M, Stenlund H, Hallmans G, Attermann J, Eriksson JW: Soluble CD36 (sCD36) Clusters with Markers of Insulin Resistance, and High sCD36 Is Associated with Increased Type 2 Diabetes Risk. J Clin Endocrinol Metab 2010, 95(4):1939-1946. 
41. Handberg A, Lopez-Bermejo A, Bassols J, Vendrell J, Ricart W, FernandezReal JM: Circulating soluble CD36 is associated with glucose metabolism and interleukin-6 in glucose-intolerant men. Diabetes Vasc Dis Res 2009, 6(1):15-20.

42. Liani R, Halvorsen B, Sestili S, Handberg A, Santilli F, Vazzana N, Formoso G, Aukrust P: Plasma levels of soluble CD36, platelet activation, inflammation, and oxidative stress are increased in type 2 diabetic patients. Free Radic Biol Med 2012, 52(8):1318-1324.

43. Alkhatatbeh MJ, Enjeti AK, Acharya S, Thorne RF, Lincz LF: The origin of circulating CD36 in type 2 diabetes. Nutr Diabetes 2013, e59. doi:10.1038/nutd.2013.1.

44. Neuparth MJ, Brandão J, Santos A, Coimbra S: Adipokines, Oxidized LowDensity Lipoprotein, and C-Reactive Protein Levels in Lean, Overweight, and Obese Portuguese Patients with Type 2 Diabetes. ISRN Obesity 2013 142097:7. doi/10.1155/2013/142097.

45. Fernández-Sánchez A, Madrigal-Santillán E, Bautista M, Esquivel-Soto J, Morales- González A, Esquivel-Chirino C, Durante-Montiel I, Sánchez-Rivera G, Valadez-Vega C, Morales-González JA: Inflammation, Oxidative Stress, and Obesity. Int J Mol Sci 2011, 12(5):3117-3132.

46. Savini I, Catani MV, Evangelista D, Gasperi V, Avigliano L: Obesity-associated oxidative stress: strategies finalized to improve redox state. Int J Mol Sci 2013, 14(5):10497-10538.

47. Himoto T, Tani J, Miyoshi H, Morishita A, Yoneyama H, Kurokohchi K, Inukai M, Masugata H, Goda F, Senda S, Haba R, Ueno M, Yamaoka G, Masaki T: Investigation of the factors associated with circulating soluble CD36 levels in patients with HCVrelated chronic liver disease. Diabetol Metab Synd 2013, 5(1):51.

48. Kopprasch S, Pietzsch J, Kuhlisch E, Fuecker K, Temelkova-Kurktschiev T, Hanefeld M, Kühne H, Julius U, Graessler J: In Vivo Evidence for Increased Oxidation of Circulating LDL in Impaired Glucose Tolerance. Diabetes 2002, 51(10):3102-3106.

49. Ruíz-Hernández N, Espinoza-Zavala M, González JC, Leal-Herrera U, Reigosa-Yaniz A: Oxidized LDL and anti-oxidized LDL antibodies according uric acid levels in overweight women. Arch Cardiol Mex 2011, 81(3):188-96.

50. Handberg A, Høilund K, Gastaldelli A, Flyvbjerg A, Dekker JM, Petrie J, Piatti P, Beck-Nielsen H, RISC Investigators: Plasma SCD36 is associated withmarkers of atherosclerosis, insulin resistance and fatty liver in a nondiabetic healthy population. J Intern Med 2012, 271(3):294-304

51. Holvoet P, Mertens A, Verhamme P, Bogaerts K, Beyens G, Verhaeghe R, Collen D, Muls E, Van de Werf F: Circulating oxidized LDL is a useful marker for identifying patients with coronary artery disease. Arterioscler Thromb Vasc Biol 2001, 21(5):844-848.

52. Holvoet P, Vanhaecke J, Janssens S, Van de Werf F, Collen D: Oxidized LDL and malondialdehyde-modified LDL in patients with acute coronary syndromes and stable coronary artery disease. Circulation 1998, 98(15):1487-1494.

53. Toshima S, Hasegawa A, Kurabayashi M, Itabe H, Takano T, Sugano J, Shimamura K, Kimura J, Michishita I, Suzuki T, Nagai R: Circulating oxidized low density lipoprotein levels: a biochemical risk marker for coronary heart disease. Arterioscler Thromb Vasc Biol 2000, 20(10):2243-2247.

54. Ehara S, Ueda M, Naruko T, Haze K, Itoh A, Otsuka M, Komatsu R, Matsuo T, Itabe H, Takano T, Tsukamoto Y, Yoshiyama M, Takeuchi K, Yoshikawa J, Becker AE: Elevated levels of oxidized low density lipoprotein show a positive relationship with the severity of acute coronary syndromes. Circulation 2001, 103(15):1955-1960.

55. Holvoet P, Kritchevsky SB, Tracy RP, Mertens A, Rubin SM, Butler J, Goodpaster B, Harris TB: The metabolic syndrome, circulating oxidized $\mathrm{LDL}$, and risk of myocardial infarction in well-functioning elderly people in the health, aging, and body composition cohort. Diabetes 2004 53(4):1068-1073.

doi:10.1186/1471-2261-14-54

Cite this article as: Ramos-Arellano et al:: Circulating CD36 and oxLDL levels are associated with cardiovascular risk factors in young subjects. BMC Cardiovascular Disorders 2014 14:54.

\section{Submit your next manuscript to BioMed Central and take full advantage of:}

- Convenient online submission

- Thorough peer review

- No space constraints or color figure charges

- Immediate publication on acceptance

- Inclusion in PubMed, CAS, Scopus and Google Scholar

- Research which is freely available for redistribution

Submit your manuscript at www.biomedcentral.com/submit
() Biomed Central 